This item was submitted to Loughborough's Research Repository by the author.

Items in Figshare are protected by copyright, with all rights reserved, unless otherwise indicated.

\title{
Towards a framework for knowledge management in project management
}

PLEASE CITE THE PUBLISHED VERSION

PUBLISHER

(C) Inderscience Publishers

VERSION

AM (Accepted Manuscript)

LICENCE

CC BY-NC-ND 4.0

REPOSITORY RECORD

Oluikpe, Paul, M. Sohail, and Frank Odhiambo. 2019. "Towards a Framework for Knowledge Management in Project Management”. figshare. https://hdl.handle.net/2134/5397. 
This item was submitted to Loughborough's Institutional Repository (https://dspace.lboro.ac.uk/) by the author and is made available under the following Creative Commons Licence conditions.

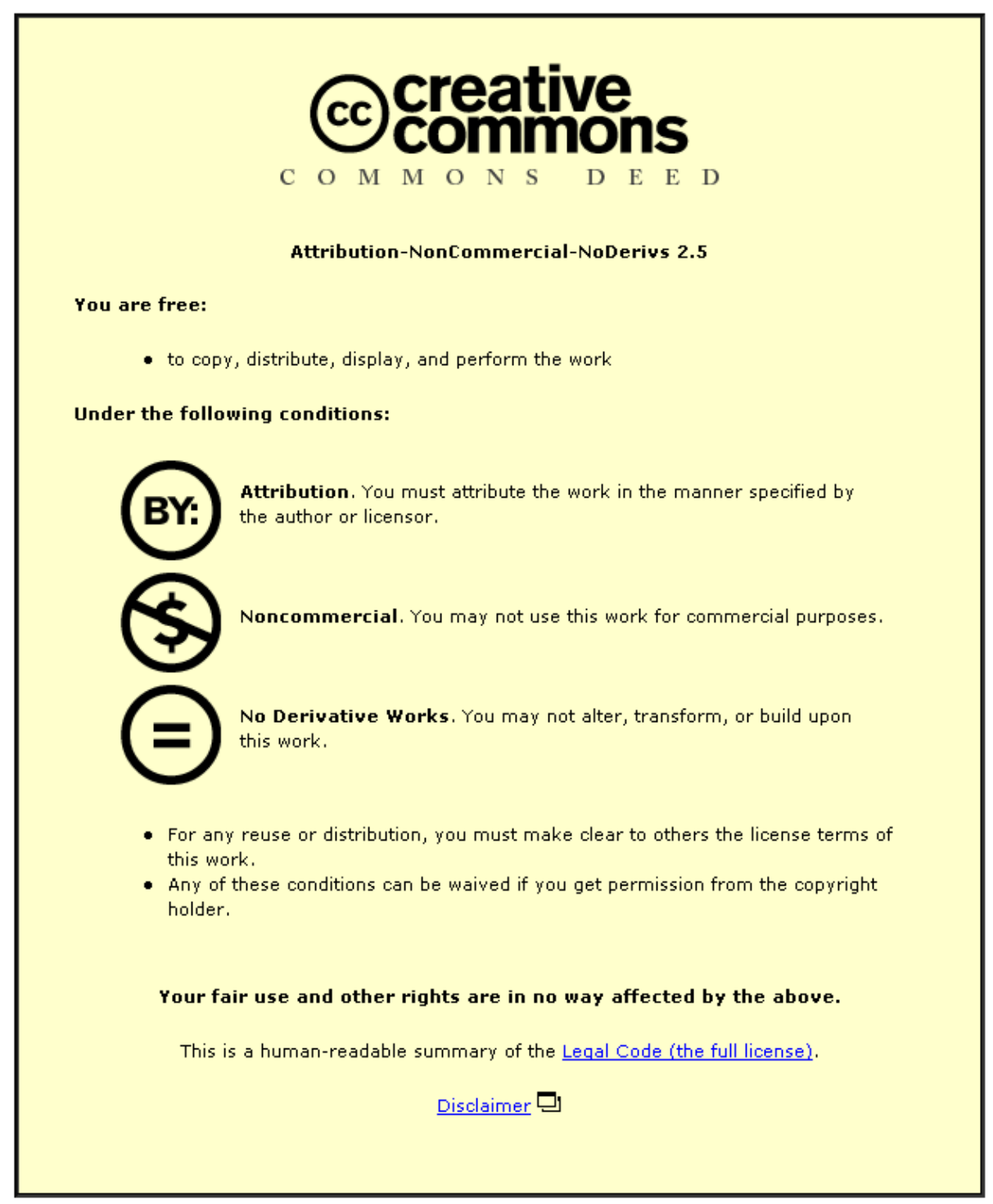

For the full text of this licence, please go to: http://creativecommons.org/licenses/by-nc-nd/2.5/ 


\title{
Towards a framework for Knowledge Management in project management
}

\author{
Paul Oluikpe*, Muhammaed Sohail and Frank Odhiambo \\ Department of Civil and Building Engineering \\ Loughborough University, Leicestershire LE11 3TU. \\ Email: p.i.oluikpe@lboro.ac.uk \\ Email: m.sohail@lboro.ac.uk \\ Email: f.o.odhiambo@lboro.ac.uk \\ ${ }^{\star}$ Corresponding author
}

\begin{abstract}
Studies have shown that knowledge management is an enabler of organisational processes and helps achieve projected objectives. This paper investigated the role of knowledge management in enabling project management to achieve project objectives. Using relevant literature of project management the research identified project success, faster completion times, operational efficiency, innovation and generation of new knowledge as dominating project management expectations in the past ten years. The research decided to study the role of knowledge management in enabling project management achieve these five objectives. An analysis of the PM process as a knowledge generating process led to the formulation of a KM model for PM. Using a quantitative approach, data was sought from 1000 respondents out of a population of 10000 from 11 project management areas in 8 world regions in order to test the conceptual model in real world scenarios. The data gathered was analysed using quantitative analysis tools (SPSS) and techniques such as reliability, correlation and regression.
\end{abstract}

Knowledge management was found to be a factor in speeding up project completion times. It was also linked to innovation, project success, operational efficiency and the generation of new knowledge. The CRAl model was linked to the five project outcomes selected by the study.

Keywords: Knowledge management; Knowledge sharing; Project management; Innovation.

Paper type: Research paper

Biographical notes: Paul Oluikpe is a Researcher at the Civil and Building Engineering department of Loughborough University. He graduated from Loughborough with a PhD in Knowledge Management and an MSc in Information and Knowledge Management. He currently works on a project dealing with extracting knowledge from post project reviews of construction companies.

Muhammaed Sohail is a Professor of Sustainable Infrastructure at the Water, Engineering and Development Centre, Loughborough University and the Director of the Doctoral programme. His research interests are in the area of knowledge management, provision of sustainable urban infrastructure through partnership policy, planning, procurement and management. 
Frank Odhiambo is a Programme Manager at the Water, Engineering and Development Centre of Loughborough University. He holds a PhD in Information Science and his research interests include knowledge management, scientific communication and capacity development. 


\section{Introduction}

Knowledge Management (KM) has been linked successfully to business performance (Carrillo et.al, 2003) therefore providing a context for its adoption as a business strategy. What $\mathrm{KM}$ seeks to do is to capture and leverage intellectual capabilities and deploy these to help projects in the course of their activities. This helps in the overall project performance and enables projects to function optimally. $\mathrm{KM}$ is not a one stop solution for projects, rather the idea behind managing knowledge is to learn from experience, to communicate, to leverage capacity and to transfer competencies among others. The benefits this brings to organisations are well documented in literature. Little wonder, $\mathrm{KM}$ has caught on as a front burner in organisational management circles leading to a wide range of theories and practical applications. As a result, there has been a paradigm shift from early project management (PM) techniques such as Management By Objectives (MBO) which concentrated on process and measurement techniques to a knowledge driven organisation point of view (Levy, 2006; Loosemore, 2006). Because projects are used to change, it is also natural that new tools and approaches to managing projects may be considered in the course of project activity. The move to a knowledge age is also suggestive of a shift in project approach. The relevance of KM to PM is linked to the increased volume and complexity of information and knowledge required during the project process (Milton, 2005). KM has provided the opportunity to drive business results in a complex project environment. Project complexity sometimes defies natural business thinking. As a result, project managers are forced to rethink the way of doing project work (Anumba et.al., 2005). First we review relevant literature of KM and PM. 


\section{Knowledge Management: Literature review}

Knowledge management is relatively new as a discipline. It has similarities with information management and business management in some aspects. This leads to some confusion in its classification. Some classify KM as information systems while others see it as human resource management (HRM). However, KM has roots to a number of disciplines which include cognitive science, information science, knowledge engineering, sociology, philosophy, management, artificial intelligence, economics and politics. Definitions of KM found in the literature come from disciplinary perspectives.

\section{$2.1 \mathrm{KM}$ perspectives}

Certain definitions of knowledge management come from the strategic management perspective (Wiig, 1997, 2000; Alavi and Leidner,2001), others approach it from the human resources perspective (Skyrme and Amidon;1997; Liebowitz, 2001) and yet another group see KM as strongly rooted in information systems (Kakabadse et.al, 2003; Lave, 1988; Blacker, 1995). However, none of these definitions are clear on their positions on the highly turbulent environments of project management which require continuous innovation, efficiency and faster delivery (completion) times and this needs to be questioned. Egbu (2006) is among the few researchers who carried out empirical studies on the benefits of knowledge production and the impact this can have on project innovation. The results of this study show that problem-solving, innovation and managing change are the triggers for knowledge production. The complex nature of project management necessitates a reliance on the benefits of knowledge management. The 
majority of writings on KM have been theoretical and ethnographic with little or no empirical studies to support assumptions. The fact is that we live in uncertain times and any assumptions about competitive advantage and approaches to project management need to be considered carefully.

\section{Knowledge management and the PM process.}

Project Management Institute (1996) defines PM as "the application of knowledge, skills, tools and techniques to project activities in order to meet or exceed stakeholder needs and expectations from a project". The project management paradigm is continuously shifting as a result of advances in information technology and globalisation. The current preoccupation of PM is to track work process, share knowledge and information among project actors and facilitate collaboration using technology where necessary (Carmichael, 2006; Hodgson and Cicmil, 2006) .

A number of criticisms have trailed traditional project management recently. One is that PM focuses on scheduling, control and quality assessment and on the other hand neglects collaboration which has been found to be necessary for project success. Project managers are said to have turned a blind eye on the challenges that face project management in current times namely: (1) Collaboration-relating to effective interaction, communication and coordination (2) $\mathrm{KM}$-capturing tacit knowledge and converting this into explicit knowledge and sharing explicit knowledge (3) Work processdocumenting and reviewing lessons learned, adopting results of post project reviews and concentrating on the work process itself (Lester, 2006; Levy, 2006; Clements, 2005). 


\subsection{The challenges facing PM.}

A number of other challenges continue to face project management in the current dispensation. These are well documented in literature. Worth particular mention are OECD (2003), which highlighted the complexity arising from distributed project work, Murdoch (2001) which related difficulties in maximising intellectual capital and Wood (2003) which mentioned the difficulties of managing individual and group knowledge in project environments. A number of other issues constitute a challenge and limit the PM process in this regard:

\subsection{Leadership problems}

Project management is faced with the challenge of leadership. This arises as a result of the difficulty in coordinating the intangible capabilities of project workers, tapping from their past experience and using this to accomplish project objectives (Disterer, 2002). The dispersed nature of current day project work makes this issue a challenging one. Project teams are often charged with providing necessary flexibility to react quickly to changes and due to the mix of team members from different functional areas, leadership is constrained to manage various capabilities to achieve project objectives. The emergence of project-teams and groups places different kinds of constraints on leadership (Weinkauf and Hoegl, 2002) as opposed to past PM management styles. Leaders are now required to be flexible, adaptive, approachable, innovative, visionary, inspirational, situational (Lee-Kelley, 2001), creative and motivational (Barber and Warn, 2005). They are widely considered an important determinant in project effectiveness (Gladstein, 
1984; Hackman, 1987). And they are required to influence attitudes and behaviour of individuals and the interaction within and between groups for the purpose of achieving goals (Bass, 1990). The PM process needs leadership support to thrive and leadership support relies on efficient information and knowledge management systems to make impact. Leaders must be seen to support the KM process and in this way provide an enabling environment for knowledge sharing and active participation.

\subsection{Lack of visible support for group mechanisms}

The inability of project management to create conducive environments for the creation of social capital limits project activities. Sometimes the formal nature of the project process is responsible for stifling the incentive to collaborate. Bourdieu (1985) defined social capital as "the aggregate of the actual or potential resources which are linked to possession of a durable network of more or less institutionalised relationships of mutual acquaintance or recognition". Social capital is the wealth or benefits that exist as a result of an individual's social relationships.

The generation of social capital among teams working in a project would help create, share and utilise knowledge which is vital for executing the project. Oluikpe (2003) studied the effect of social capital in innovating in a work community. This research found that social capital is vital to innovation and that communities or teams rely mostly on the network of relationships and mutual obligations arising from a loose or compact network of work relationship. The failure of project management to take on board community 
collaboration may arise from age-old traditional PM styles which institutionalise the role of management as surveillance instruments as opposed to collaboration, trust, informality and mutual participation which characterises the knowledge economy.

\subsection{Inability to capture and codify core project knowledge.}

Leseure and Brookes (2004) identified two types of project knowledge: Core and ephemeral knowledge. Core knowledge is the type of knowledge that is regarded as kernel knowledge, often sitting at the core of the project organisation. This type of knowledge is responsible for the independent execution of projects and qualifies to be tagged as an intangible asset. It is the type of knowledge that should remain and be nurtured within a project in order to achieve and sustain high project performance. On the other hand, the other type of knowledge is called ephemeral knowledge deriving from its nature to help achieve project completion though there is no guarantee that this type of knowledge would ever be used in future projects. In effect, ephemeral knowledge is useful and specific to certain projects. These two types of knowledge are crucial to a project and need to be leveraged through a KM strategy. Disterer (2002) highlighted the challenges projects face in capturing knowledge of staff who have dispersed at the completion of the project. He sees this as a major challenge citing that unless staff knowledge is captured before they leave the project, some aspects of the project knowledge would need to be reinvented whenever it is needed. 


\subsection{Reinvention of the wheel.}

Re-invention of the wheel is abundant in project execution. Most projects begin to learn over again what could have been learnt from a similar project somewhere because there is no avenue to share and transfer knowledge. Knowledge sharing is an essential part of PM. Social interaction leverages knowledge sharing and impacts positively on projects (Chua, 2003). An important agenda of $\mathrm{KM}$ initiatives within a project is to foster knowledge sharing among project members (Trussler, 1998). Knowledge sharing is too important to be left at the sole discretion of organisational members. A major impediment to knowledge sharing is a lack of top down management support for knowledge sharing activities. PM should be seen to encourage visibly, the sharing of knowledge through establishing strategies for supporting sharing of knowledge among staff. Some of these strategies include using technology, introducing incentive schemes, cultivating communities of practice, providing role models, and creating centres of excellence across functional divisions.

\subsection{Inadequate learning from projects}

There are frequent suggestions that formal systematic learning is of lesser importance than informal learning. For example, both Garrick's (1998) analysis of the building industry and Boud's (1999) consideration of the academic profession suggest that informal interactions with peers are predominant ways of learning and that the impact of formal training on practice can be quite marginal. Secondly, it has been argued that the person who is nominally expected by organisations to foster learning in the project team- the project manager- may be unable to do so effectively because of the 
structural constraints of their role. (Hughes,2000) has suggested that staff can have difficulties in trusting managers to facilitate their learning because of their formal role in surveillance of staff and the need for individuals to portray themselves as competent workers.

What is needed by PM therefore is an integrated framework for managing knowledge to facilitate project learning. Before proposing a framework for managing knowledge in $\mathrm{PM}$, we review and critique a number of knowledge management models below:

\subsection{Knowledge management models:}

A number of KM models which may be useful for project management exist in the literature of KM. Some of these are presented and critiqued briefly in this section:

\subsubsection{CAPRIKON:}

Table 1: Knowledge Processes by Tan et al (2006)

\begin{tabular}{|l|l|l|l|l|}
\hline Caprikon & $\begin{array}{l}\text { Robinson et al. } \\
(\mathbf{2 0 0 1 )}\end{array}$ & $\begin{array}{l}\text { Kululanga \& } \\
\text { McCaffer (2001) }\end{array}$ & Bhatt (2001) & Rollett (2003) \\
\hline Capture & & & & \\
\hline Identifying & Discovering & Acquiring & Creation & Planning \\
\hline Locating & Locating & Creating & & Creating \\
\hline & Capturing & & & Assessing \\
\hline Representing & Organising & Storing & Presentation & Integrating \\
\hline Storing & Storing & & & Organising \\
\hline Validating & & & Validation & Transferring \\
\hline & & & & \\
\hline Sharing & & & & \\
\hline Sharing & Sharing & Sharing & Distribution & \\
\hline & Transferring & & & \\
\hline & & & & \\
\hline Reuse & & & & \\
\hline Adapting & Modifying & Utilising & Application & \\
\hline Applying & Applying & & & \\
\hline & & & & \\
\hline Maintain & & & & \\
\hline Archiving & Archiving & & & \\
\hline Retirement & Retirement & & & \\
\hline & & & & \\
\hline & & & & \\
\hline
\end{tabular}


This is one of the most explicit processes in literature expostulated by Tan et al (2006). Table 1 above depicts the CAPRIKON and compares it with other typical knowledge processes. According to this model, knowledge capture encapsulates identifying and locating knowledge and knowledge representation involves storing and validating knowledge. Knowledge sharing deals with the transfer of knowledge to the right people at the right time (Robinson et al, 2001). Knowledge can be transferred between people and computers. People can also interact with computer systems thereby eliciting knowledge transfer. The next step in the knowledge process is knowledge reuse. This process involves adapting and applying knowledge gained for problem solving. Ideas could be reused and applied for innovative ends through developing such ideas fully and reconceptualising the problems they are meant to solve. In this way, there is a continual flow of knowledge in a cycle leading to use and reuse and in each scenario, the knowledge adapted and used emerges in a different and improved form. Knowledge reuse leads to its maintenance which relates to archiving and retiring such knowledge for subsequent use. It also involves updating what is obsolete and refining it to keep abreast of developments in the area.

\subsubsection{Nonaka and Takeuchi's knowledge creation model:}

Other KM models identified in literature include the Knowledge Creation model (Nonaka and Takeuchi, 1995) which describes the process of knowledge creation and categorised knowledge into tacit and explicit. Perhaps, the usefulness and relevance of this model could be much more attributable to its categorisation of the kinds of knowledge (tacit and explicit) and the identification of four levels of interaction of knowledge in a process.

\section{Take in Figure (No.1)}

\subsubsection{Boisot's model:}

Boisot's (1987) model considers knowledge as either codified or uncodified. It also considers it as diffused or undiffused within an organisation. The term codified in this context refers to knowledge that can be easily prepared for 
transmission and the term uncodified refers to knowledge that cannot be easily prepared for transmission. The term diffused refers to knowledge that can be readily shared while undiffused refers to knowledge that is not readily shared. There are a number of similarities between Nonaka's and Boisot's models. Nonaka's categorisation of tacit and explicit knowledge bear some resemblance to Boisots classification of uncodified and codified knowledge. In both models also, the horizontal aspects of the model relate to the diffusion or spread of knowledge across the organisation.

Take in Figure (No.2)

\subsubsection{Intellectual Capital Model}

A typical Intellectual Capital (IC) model is the Skandia intellectual capital model from Chase (1997). The model assumes that IC or KM can be broken down into human, customer, process and growth dimensions contained in two main categories of human capital and organisational capital. The Skandia example tries to bring a measurement approach to KM elements assuming it can be tightly controlled just like tangible assets. This approach may result in placing objective measures on issues which are subjective.

Take in Figure (No.3)

\subsubsection{Social Construction model:}

Demerests (1997) model highlights the construction of knowledge within the organisation and does not limit the process to scientific approach but also involves the social construction of knowledge. Knowledge is embodied not just through explicit programmes but also through a process of social interchange. This model is more balanced in view than the previous models in that it is not mechanistic but is inclusive of social interchange.

Take in Figure (No.4)

The next section discusses the development of the framework and the survey design. 


\section{Towards a KM framework for Project Management}

Utilising the project management process, this paper tried to identify knowledge processes within the PM stages. A basic assumption is that the project process is also a knowledge generating process. Therefore the PM cycle which is a basic instrument of managing projects represents a knowledge cycle. What this paper has done is to examine the processes and typical activities that go from identification to evaluation stages of a project in the light of a knowledge generation process. It also treated the four KM enablers of technology, culture, people and strategy as the inner crust of a KM programme within the PM process. This paper proposes the CRAI model as a theoretical model for knowledge management in the PM process.

A combination of $\mathrm{KM}$ and PM ontology resulted in the development of four elements of a KM process which the authors consider suitable for formulating a KM model for project management. Figure 5 below presents the PM cycle as a knowledge generating cycle, providing a basis for formulating the conceptual model. Figures 6 and 7 depict the conceptual model and the processes of knowledge creation, sharing and use in a PM process. What follows is a discussion of the constructs that constitute the CRAI model as proposed by this paper.

Take in Figure (No.5)

Take in Figure (No.6)

Take in Figure (No.7) 


\section{The model constructs.}

This section explains the four constructs of the model as represented in figures 6 and 7 .

\subsection{Interpretation (Interpretative knowledge).}

Each project begins with an interpretation, analysis, and detailed consideration of project information, requirements and specifications. To deliver a project well, one must understand why it is needed and what it is for at the start of the planning process. The client explains their requirements, stakeholders are able to get across their views about the project and what they require. This stage is the preliminary stage of interpretation and planning, (Muriithi and Crawford, 2002) where things are made clear. First, interpretative knowledge takes into consideration the people aspect of $\mathrm{KM}$ which relates to recruitment, qualifications, staff experience, training and knowledge of the project (Farr-Whatton, 2003). A good project staffing practice will enhance working relationships and increase the potential for knowledge creation and sharing (Kotnouor, 2000). Second, technology tools support the sense making process as the staff try to make meaning of documentation and what they are supposed to do during the project process (Odhiambo, Harrison and Hepworth, 2003). Third, the strategy perspective of interpretative knowledge relates to the projects ability to schedule project times, manage sudden and unexpected change, plan for risk management and manage the project process effectively. And finally, The culture 
dimension relates to the knowledge available in the form of project leadership, resource base, project capacity and organisational memory. The knowledge available to a project in this respect enhances the progression of the project from the identification stage to the other stages.

\subsection{Assimilation (Assimilative Knowledge)}

The assimilation stage of the project $\mathrm{KM}$ process relates to the interaction happening among team members through informal communities, team work, review meetings and networks. Research has linked a projects information utilisation capacity to the existence of group mechanisms (Galbraith, 1973; Gupta and Govindarajan, 2000). Innovation flows more efficiently through relationships in and outside a project (Tushman and Scanlan, 1977; Ghoshal and Bartlett, 1988; Nobel and Birkinshaw,1998; Hansen, 1999), and best practices are transferred more easily when there is a relationship between two parties to knowledge transfer (Szulanski, 1996). Hansen (2002) researched on knowledge sharing between project teams and linked project completion time to the rate of knowledge sharing among teams.

\subsection{Reproduction (Reproductive knowledge).}

The reproduction process is the implementation stage. At this stage, knowledge residing in design details and in the heads of team members is made tangible. The project outcome (infrastructure) is the product of tacit and explicit knowledge. Tacit knowledge which is in a state of doing (empirical) and explicit knowledge which is in a state of being (idealist) are combined and reproduced into project outputs. Knowledge creation in itself is not profitable if it's not translated into project outcomes. The reproductive stage in the 
model is enabled by knowledge creation, sharing and utilisation. At this stage the core competencies (entrepreneurial competencies, technical competencies, evaluative competencies, and relational competencies) of PM as identified by Lampel (2001) are brought to the fore. Some of the elements that constitute the various processes and ingredients for successful reproduction of project design into project outcomes are: knowledge creation; refining and use and reuse (culture dimension); quality management; work breakdown structure (WBS); communication (strategy dimension); leadership; team work; reviews (people dimension); integrative technology; search and retrieval; databases and collaborative technology (technology dimension).

\subsection{Codification(Codified knowledge).}

The codification stage of the KM (conceptual) model is the evaluation stage of the PM process. Towards the conclusion of a project, relevant knowledge and information are documented and passed on as evaluation reports, summaries of project activity, appraisals, project brief and debriefings (Schindler and Eppler, 2003). These documentation attempt to capture the knowledge of staff who worked on these projects. Post project reviews (PPR) have been recognised as strategies for capturing and codifying project knowledge (Carrillo, 2005). Although documentation may contain project knowledge, they are often not in readily usable format to enable decision making. Research has been carried out in the area of learning from post project reviews (Terry, 2004; Carrillo, 2005). Post project review meetings, evaluation reports, and lessons learned databases offer a rich source of knowledge for projects if they have the time to analyse them. In theory, organisations have PPR and review meetings but in practice they are frequently not in place (von Zedtwitz, 2003). 
This makes organisations miss the opportunity to learn from important mistakes or successes of a project. Capturing and codifying project knowledge throughout the project process will lead to the generation of new knowledge if the captured knowledge is subsequently analysed and utilised (Argyris, 1999; Disterer; 2002; Bowen et.al, 1994). The next section discusses the five PM expectations chosen by this paper and the theoretical framework behind this.

\section{Current PM expectations}

The project outcomes chosen for this paper follows from (Crawford, Pollack and England, 2006) who researched the key themes of PM journal articles over the past 10 years. This research considers (Crawford, Pollack and England, 2006) results as indicative of the current PM expectations. The five outcomes chosen are outlined in the sections below:

\subsection{Innovation.}

Innovation is defined as "a mentality that expresses itself through learning" and "a knowledge process aimed at creating new knowledge and geared towards the development of commercial and viable solutions" (Harkema, 2003). Innovation similarly will be defined as "a process wherein knowledge is acquired, shared and assimilated with the aim to create new knowledge" (Coleman, 1999). Another approach towards innovation is based on looking at innovation as a process and flow of knowledge, rather than a set of actions or outputs. This approach regards knowledge as far broader than simple information or data processing. Looking at innovation as a knowledge process 
opens a new perspective on the interactions among innovation and creativity (Wheatley, 1992).

An innovation project is a project in which one plans to realize new knowledge (Samid,2003). The essence of innovation is knowledge realization. From the $\mathrm{KM}$ angle, the metrics for innovation content is the quantity of newly realized knowledge as a result of the project carried out. Innovation is not a new term in PM. It is widely considered as the capability to invent new ways of project implementation or improving on already existing capabilities.

\subsection{Completion times.}

Project completion time can be measured as the extent to which the project is finished on schedule, (Ancona and Caldwell,1992). One of the ways to measure completion time is to group projects according to some similarity measure and then take a project's deviation from the mean completion time of the group (Eisenhardt and Tabrizi,1995). In recent decades, completion times have become a major constraint for projects. It is mostly against this index that clients determine whom to give contracts and whom not to give. Projects which promise to deliver on time stand better chances of winning contract bids. Part of the objective of this paper is to investigate whether KM plays a significant part in fostering faster completion times during the PM process. Project members interact and cooperate in order to accomplish the work and complete the project on time. Cooperation and interaction among team members promote the sharing of project knowledge leading to shared understanding, collective vision, and achievement of objectives. 


\subsection{Project success.}

Success is measured as a project that was on-time, on-budget, and that met product specification. A project failure, the authors believe, can only occur if there is customer discontent. If cancelled, the project may not be a failure. Cancelled projects could generate a lot of knowledge that could be directly transferred to the next project. A project being in time, on schedule, on cost and meeting specifications does not mean it is successful. From a KM perspective, the measure of success is the amount of knowledge that could be carried on to future projects (Dalgleish, 2003). A project which achieved projected results but does not offer the opportunity of team members ever working together again maybe due to communication breakdown or team dispersal may still yield a lot of knowledge for future projects. Other projects within the same organisation may learn from what happened during this project and try to avoid the pitfalls.

\subsection{Operational efficiency.}

Operational efficiency involves finding the best ways to deliver a project, eliminating repetitive and low-value tasks, reducing risk and improving quality and eliminating errors associated with certain manual or automated tasks. From the KM perspective, operational efficiency is maximised when knowledge is shared and utilised. Organizations must examine baseline operational processes that support the project, and then plan, implement, and support the right procedures using $\mathrm{KM}$ processes. Being process-driven means the operations that support business activities become highly efficient. 
Only with well thought-out project processes in place from the ground up and a leveraging through $\mathrm{KM}$ can an organization achieve operational efficiency. Operational efficiency is - what occurs when the right combination of people, process, and technology come together to enhance the productivity and value of any project, while driving down the cost of routine operations to a desired level. The end result is that resources previously needed to manage operational tasks can be redirected to new, high value initiatives that bring additional capabilities to the project organization.

\subsection{New Knowledge.}

Knowledge creation is the process of realising new knowledge from the whole project process. The combination of knowledge creation, sharing and utilisation features of a project are factors which help yield new knowledge for a project. Knowledge realised in a project are utilised for reproducing project specifications and meeting clients needs. Project success is seen to anchor on the creation and realisation of new knowledge during the project process. Innovation is often linked to the realisation and utilisation of new knowledge leading to cutting edge delivery of products and services. PM strategies are focusing on ways of stimulating innovative practices using collaborative knowledge activity.

Having identified and described five current PM expectations, the paper goes

forward in the next section to design a survey for testing the relationship of KM to these PM expectations. 


\section{Methodology}

The potential study population was 10,000 but this was narrowed to a sample size of 1000 using a stratified random sampling technique which took into consideration the project areas and the regions projects were drawn from. The authors selected projects based on a random review of three project databases which covered the 11 project areas selected for the study as found in Table 1. These databases were secured from an academic institution, a construction and design company and a centre for water and engineering services which all participated and collaborated in the research.

Table 1: Project regions and project areas selected for study

\begin{tabular}{|c|c|}
\hline Project region & Project areas \\
\hline 1. Europe & 1. Construction. \\
\hline 2. North America & 2. Water and Sanitation. \\
\hline 3. Latin America & 3. Education. \\
\hline 4. The Caribbean & 4. Technology. \\
\hline 5. Sub-Saharan Africa & 5. Social services. \\
\hline 6. North Africa & 6. Sustainability. \\
\hline 7. East Asia & 7. Information. \\
\hline 8. The Pacific & 8. Women Welfare. \\
\hline 9. Central Asia & 9. Children and Youth Services. \\
\hline 10. South Asia & 10. New Product Development. \\
\hline 11. Australia & 11. Design. \\
\hline 12. Middle East & \\
\hline
\end{tabular}

Table 1 shows the project regions and areas selected for this study while Table 2 shows the stratified random sampling of projects based on the regions. 
A web questionnaire was developed to enable the authors to gather information faster and more effectively. It was discovered that most project contacts for this survey had email addresses so this was considered more convenient for data collection both for the authors and the respondents. Table 2 presents the stratified random sampling of projects for this study.

Table 2: Stratified sampling of projects from regions

\begin{tabular}{||l||l||l||l||}
\hline \hline Regions & No. selected & Percentage & Cumulative \% \\
\hline \hline Europe & 150 & 15 & 15 \\
\hline \hline North America & 150 & 15 & 30 \\
\hline \hline Latin America & 70 & 7 & 37 \\
\hline \hline The Caribbean & 70 & 7 & 44 \\
\hline \hline Sub-Saharan Africa & 70 & 7 & 51 \\
\hline \hline North Africa & 70 & 7 & 58 \\
\hline \hline East Asia & 70 & 7 & 65 \\
\hline \hline The Pacific & 70 & 7 & 72 \\
\hline \hline Central Asia & 70 & 7 & 79 \\
\hline \hline Australia & 70 & 7 & 86 \\
\hline \hline Middle East & 70 & 7 & 93 \\
\hline \hline South Asia & 70 & 7 & 100 \\
\hline \hline
\end{tabular}

The questionnaire was structured on a six-point likert scale ranging from strongly disagree to strongly agree. Respondents were required to show their degree of agreement or disagreement with the statements made under each construct of the model. About 36 questions were designed and placed randomly in the questionnaire to avoid response bias. Section A of the questionnaire asked general and background questions on responding projects. Section B sought information on aspects of the study such as the model constructs (interpretation, assimilation, reproduction and codification) and the PM expectations of innovation, project success, completion times, 
operational efficiency and generation of new knowledge. Prior to administration of the survey, the questionnaires were sent out to 10 project managers in a pilot survey to control for response bias and to ensure that they understood the terms used in the questionnaire. Adjustments were made accordingly, based on the feedback received in the pilot survey. Table 3 shows the various sections of the questionnaire in detail.

Table 3: Questionnaire coding

\begin{tabular}{||l||l||}
\hline \hline \multicolumn{1}{||c||}{ SECTION A: GENERAL } & SECTION B: PROJECTS \\
\hline \hline Project Region & Interpretation \\
\hline \hline Project Size & Assimilation \\
\hline \hline \hline Project Type & Reproduction \\
\hline \hline Project Duration & Codification \\
\hline \hline No. of staff on Project & Project Completion Time \\
\hline \hline Project Role of Staff & Project Success \\
\hline \hline Project Communication tools & Best Practices \\
\hline \hline Knowledge sharing tools & Innovation \\
\hline \hline \hline \hline & Operational Efficiency \\
\hline \hline
\end{tabular}

Over a period of five months responses were received from different project contacts. The response rate is 303 which represents $30.3 \%$ of the sample size. This response rate is high considering that some studies are of the view that a good response rate is in the region of $20 \%$ and above (Kardas and Milford, 1996).

\section{Data analysis}

Data gathered in this study is analysed in the following sections: 


\subsection{Reliability}

The questionnaire items on Interpretation (10 items), Assimilation (6 items), Reproduction (10 items), Codification (5 items), were tested for reliability using SPSS Scale (reliability analysis function). The measurement criteria selected is the Cronbach's Alpha which measures internal consistency. The items under each construct were entered into the SPSS scale (reliability analysis function) and computed for Cronbach's Alpha. The result is shown in Table 4.

Table 4: Reliability statistics

\begin{tabular}{||l||r|r||r||r||}
\hline & Count & $\begin{array}{r}\text { Mean } \\
\text { Statistic }\end{array}$ & $\begin{array}{r}\text { Standard } \\
\text { Deviation }\end{array}$ & $\begin{array}{r}\text { Cronbach' } \\
\text { s Alpha }\end{array}$ \\
\hline \hline INTERP & 303 & 19.2 & 3.1 & 0.628 \\
\hline \hline ASSIM & 303 & 20.3 & 2.4 & 0.816 \\
\hline \hline REPROD & 303 & 24.5 & 2.9 & 0.719 \\
\hline \hline COD & 303 & 19.8 & 2.4 & 0.731 \\
\hline \hline Project Success & 303 & 4.9 & 1.1 & 0.79 \\
\hline \hline Innovation & 303 & 4.8 & 1.2 & 0.63 \\
\hline \hline Completion times & 303 & 4.9 & 1.1 & 0.60 \\
\hline \hline Operational efficiency & 303 & 5.2 & .97 & 0.62 \\
\hline \hline Knowledge generation & 303 & 5.1 & 1.1 & 0.76 \\
\hline \hline
\end{tabular}

Interpretation has a reliability of 0.628 alpha, assimilation has 0.816 , reproduction has 0.719 while codification has 0.731 . Interpretation has the lowest alpha score, however Robinson, Sharer and Wrightsman (1991) reported that data with 0.6 alpha is reliable for initial studies which is developmental. This study is at its developmental stages and one construct out of four with 0.628 reliability is therefore acceptable at this stage. These results are high and indicate that the constructs measure the population they are meant to measure. The validity of the constructs such as their convergent, discriminant and nomological validity is less easy to determine apart from using the correlation findings in Table 6 . Evidence demonstrating validity 
would be easier if such constructs were already operationalised within the literature and could be used as part of the questionnaire. This was not the case.

\subsection{Descriptives}

Data collected from this survey was fed into SPSS for analysis and was interpreted. Table 5 shows the survey response from regions, project areas and also according to project duration. Information projects topped the rate of response (58). Technology (54), Education (52) and Construction (45) were second, third and fourth highest responding projects. The duration of $46 \%$ of projects lie between 0 and 1 year, $74.8 \%$ are running between 0 and 2 years, and $90.1 \%$ of projects run between 0 and 3 years. In effect, above $90 \%$ of projects surveyed expect to complete within 3 years. Just over $9 \%$ of projects fall within the category of $4+$ years.

Table 5: Descriptives

\begin{tabular}{|l|l||l||r||l|l|}
\hline Project area & NO & Duration & NO & Region & NO \\
\hline \hline Construction & 45 & Under 1yr & 74 & Europe & 100 \\
\hline \hline Water & 11 & 1 Year & 65 & $\begin{array}{l}\text { North } \\
\text { America }\end{array}$ & 66 \\
\hline \hline Education & 52 & 2 Years & 87 & $\begin{array}{l}\text { Latin } \\
\text { America }\end{array}$ & 28 \\
\hline \hline Technology & 54 & 3 Years & 46 & $\begin{array}{l}\text { The } \\
\text { Caribbean }\end{array}$ & 6 \\
\hline Social & 20 & 4 Years & 17 & $\begin{array}{l}\text { Sub- } \\
\text { Saharan } \\
\text { Africa }\end{array}$ & 10 \\
\hline \hline Sustainability & 13 & 5 Years & 9 & North Africa & 12 \\
\hline \hline Information & 58 & $5+y r s$ & 4 & East Asia & 11 \\
\hline Women Welfare & 9 & Total & 302 & The Pacific & 14 \\
\hline \hline Children & 6 & System & 1 & Central Asia & 6 \\
\hline \hline $\begin{array}{l}\text { New Product } \\
\text { Development }\end{array}$ & 25 & & & South Asia & 19 \\
\hline \hline Design & 10 & & & Australia & 15 \\
\hline \hline & & & & Middle East & 16 \\
\hline \hline Total & 303 & & 303 & & 303 \\
\hline
\end{tabular}


As could be seen Europe had a response of 33\%, North America, 22\%, and Latin America 9.2\%. It is not readily apparent why response rates in the other regions apart from Europe and North America were low. But looking at the internet usage statistics, one would conclude that usage in Europe and North America expectedly is higher than obtained in other regions of the world.

\subsection{Correlation analysis}

Table 6: Correlation of variables

\begin{tabular}{|l|l|l|l|l|l|l|l|l|l|}
\hline & $\mathrm{Y}_{1}$ & $\mathrm{Y}_{2}$ & $\mathrm{Y}_{3}$ & $\mathrm{Y}_{4}$ & $\mathrm{Y}_{5}$ & $\mathrm{X}_{1}$ & $\mathrm{X}_{2}$ & $\mathrm{X}_{3}$ & $\mathrm{X}_{4}$ \\
& & & & & & & & & \\
\hline $\mathrm{Y}_{1}:$ Project Success & 1 & .36 & .15 & .06 & .01 & .04 & .59 & .25 & .01 \\
\hline $\mathrm{Y}_{2}:$ Innovation & .36 & 1 & .15 & .13 & .02 & .01 & .33 & .51 & .06 \\
\hline $\mathrm{Y}_{3}:$ Completion times & .15 & .15 & 1 & .01 & .05 & .28 & .10 & .44 & .02 \\
\hline $\mathrm{Y}_{4}:$ Operational efficiency & .06 & .13 & 1.3 & 1 & .01 & .00 & .48 & .05 & .00 \\
\hline $\mathrm{Y}_{5}:$ Generation of new knowledge & .00 & .02 & .05 & .01 & 1 & .05 & -.00 & .36 & .51 \\
\hline $\mathrm{X}_{1}:$ Interpretation & .04 & .01 & .28 & .00 & .05 & 1 & .07 & .11 & .10 \\
\hline $\mathrm{X}_{2}:$ Assimilation & .59 & .33 & .10 & .48 & .00 & .07 & 1 & .24 & .09 \\
\hline $\mathrm{X}_{3}:$ Reproduction & .25 & .51 & .44 & .05 & .36 & .10 & .11 & 1 & .42 \\
\hline $\mathrm{X}_{4}:$ Codification & .01 & .06 & .02 & .00 & .51 & .10 & .09 & .42 & 1 \\
\hline
\end{tabular}

Table 6 above shows the correlations of the variables with each other.

Project success strongly correlates with innovation, assimilation and reproduction. This shows that the way teams share knowledge (assimilation) and innovate will lead to effective reproduction of the knowledge shared during the implementation period. Completion times are strongly correlated with interpretation and reproduction showing that the way projects are planned at the beginning (interpretation) and the way they are executed (reproduction) are factors in completing on time. This paper made these points earlier during the design of the conceptual model. Generation of new knowledge have strong correlations with reproduction and codification. What this implies is that new knowledge is realised during the implementation and winding up stages of the project. This doesn't discount the fact that new 
knowledge can be realised in any stage of the project, however, the utilisation of new knowledge is at the peak during the implementation (reproductive) stage and it is often harvested and made tangible during the review and evaluation stage (codification).

\subsection{Regression analysis}

Table 7: Regression analysis

\begin{tabular}{|l|l|l|l|}
\hline Variables & B & $\beta$ & t \\
\hline Constant & 0.69 & & 0.99 \\
Project Success & 1.05 & 0.05 & 1.52 \\
Innovation & 1.11 & 0.46 & 4.6 \\
Completion times & 0.69 & 0.18 & 0.99 \\
Operational efficiency & 1.94 & 0.62 & 3.11 \\
Generation of new knowledge & 8.24 & 0.12 & 1.22 \\
R & .561 & & \\
R(Square) & .314 & & \\
F Stat & 34.17 & & \\
Sig. & 0.000 & & \\
Df & 4 & & \\
\hline
\end{tabular}

The elements of the model used in the regression analysis include Interpretation, Assimilation, Reproduction and Coding. The dependent variables are project success, innovation, completion times, operational efficiency, and generation of new knowledge. The variables in the regression are represented in this typical equation

$Y=b 1 X 1+b 2 X 2+\ldots+A$

$Y$ is the dependent variable we are trying to predict, $X 1, X 2$ and so on are the independent variables we are using to predict it, $b 1, b 2$ and so on are the coefficients or multipliers that describe the size of the effect the independent 
variables are having on the dependent variable $Y$, and $A$ is the value $Y$ is predicted to have when all the independent variables are equal to zero.

In analysing the regression of the CRAI model against the five dependent variables (project success, innovation, completion times, operational efficiency and generation of new knowledge) multiple regression was used using the stepwise selection method. The criteria used for entry into the regression equation was the computed probability of the $F$ statistic (Probability of F-to-enter $(\mathrm{PIN})$ ) is less than 0.05 . The first independent variable was examined for removal as in backward elimination using the POUT (probability of F-to-remove) criteria of 0.10 . This process was continued with all the variables in the equation and provided the results shown in Table 7. The R-Square of 0.314 indicates that our model fits the data fairly well and almost $31 \%$ of the variability in the data can be explained by the above regression equation.

Further stepwise multiple regression analyses were carried out on the five PM expectations and the results are expressed below:

Table 9: Stepwise multiple regression of variables

\begin{tabular}{|l|l|l|l|l|}
\hline & $\begin{array}{l}\text { Interpretation } \\
+(\text { Rsq) } \\
\text { Assimilation }\end{array}$ & $\begin{array}{l}\text { Reproduction } \\
(\mathrm{RSq})\end{array}$ & $\begin{array}{l}\text { Codification } \\
(\mathrm{Rsq})\end{array}$ & Sig. \\
\hline $\begin{array}{l}\text { Project } \\
\text { success }\end{array}$ & .349 & .012 & .009 & 0.05 \\
\hline Innovation & .114 & .200 & .028 & 0.05 \\
\hline $\begin{array}{l}\text { Completion } \\
\text { times }\end{array}$ & .089 & .163 & .062 & 0.05 \\
\hline $\begin{array}{l}\text { Operational } \\
\text { Efficiency }\end{array}$ & .240 & .000 &. .000 & 240 \\
\hline $\begin{array}{l}\text { G. of new } \\
\text { knowledge }\end{array}$ & .003 & .145 &. .165 & 0.05 \\
\hline
\end{tabular}


In a hierarchical multiple regression, Interpretation and Assimilation were entered in the first step and explained about $34.9 \%$ of the variance in project success $(F 2,300=80.467, \mathrm{p}<0.05), 11.4 \%$ of the variation in innovation $(F 2,300=86.979, p<0.05), 8.9 \%$ of the variation in completion times $(F 2,300=14.71, p<0.05), 24 \%(F 2,300=47.41, p<0.05)$ of the variation in operational efficiency and $0.03 \%$ of the new knowledge, each explaining a similar proportion of the variance. Reproduction was entered second and explained a further $1.2 \%(F 1,299=5.816, p<0.05)$ of the variance in project success, $20 \%(F 1,299=86.98, p<0.05)$ of the variation in innovation, $16.3 \%$ of the variation $(F 1,299=65.11, p<0.05)$ in completion times, an insignificant effect on operational efficiency, and $14.5 \%(F 1,299=51.08, p<0.05)$ of the variability observed in generation of new knowledge. Codification was entered third and explained another $0.9 \%(F 1,298=4.167, p<0.05)$ of the variance in project success, $2.8 \%(\mathrm{~F} 1,298=12.9, \mathrm{p}<0.05)$ of the variation in innovation, $6.2 \%$ of the variation in completion times $(F 1,298=27.11, p<0.05)$, insignificant effect on operational efficiency and $16.5 \%(F 1,298=71.42, p<0.05)$ of the variability observed in generation of new knowledge. Ideally, we would have liked to explain most if not all of the variations in the variables as outlined above. However, the results above establish a positive link between our model and the variables.

\section{Discussion and conclusion}

This section summarises the highlights of the paper and concludes with some recommendations for project management. 


\subsection{Summary}

Knowledge management has been said to hold some benefits for project management. This paper has explored the potential benefits of KM for project management using a conceptual model developed after analysing the project management process as a knowledge generating process embedded in the four KM dimensions of people, strategy, culture and technology. Specifically, the paper explored relationships between the proposed $\mathrm{KM}$ model and five current project management expectations through a survey of projects.

It collected and analysed data from 1000 projects across 12 world regions. The Statistical Package for the Social Sciences (SPSS) was used to analyse the data collected through regressions and correlations. Before analysis, the survey data was tested for reliability and this showed a minimum reliability coefficient of 0.6 (Cronbach's Alpha) for interpretation and higher for other constructs. This indicates that the data gathered in this survey is reliable and can be used for making predictions and conclusions in the course of the analysis of data.

A correlation analysis of the CRAI model and the current PM expectations namely: project success, innovation, efficiency, completion times and generation of new knowledge was carried out. In each case, the CRAI model was proved to have a positive and significant relationship with each element (deliverable) of the hypothesis. The regression analysis established that $\mathrm{KM}$ in project management is positively related to project success, innovation, operational efficiency, completion times and generation of new knowledge. 
Interpretation and Assimilation seem to play a more important role in project success than Reproduction and Codification. This implies that the initial processes of combining the experience and qualifications of staff in a mix of communication and collaboration in teams play very crucial roles in enabling knowledge for successful project execution.

\subsection{Conclusion}

Based on the analysis above, we conclude with the following recommendations for project management:

1. Project management organisations should begin to design $\mathrm{KM}$ strategies as part of PM systems. Knowledge management should be seen as a component part of PM to make sense. The nature of PM which includes collaboration makes KM essential.

2. Knowledge management should be included as part of the PM Body of Knowledge. It should be regarded as a specific PM area of competence.

3. KM should also be included in the list of critical success factors for project management.

4. Project management software manufacturers need to tailor their products towards integrating $\mathrm{KM}$ capabilities in PM systems. This would enable project managers and staff work with knowledge-based PM tools.

5. It is recommended that PM should pay closer attention to the existence of communities in the project. Management should be seen to encourage the growth and development of communities of practice 
within the project as this holds the potential for creating and leveraging innovation, best practices, project success, knowledge sharing, efficiency and faster completion times.

6. Projects should look into adopting and experimenting with the CRAI model of KM to enable them gain the benefits this model could bring to PM. Future studies on the CRAI model is strongly recommended.

7. Strategies need to be mapped out by PM to capture and codify knowledge realised during the project process to avoid re-invention of the wheel. Various research have made this point but it appears projects still have problems capturing and codifying project knowledge. The prevalence of project mistakes, cost and time overrun and consequent project failure suggest that critical project knowledge is often lost during the process and thus projects begin afresh to learn.

8. The people aspects of PM are very important and need careful consideration in the PM process. With the advent of the knowledge economy, people have assumed more importance than materials, money and methods and projects which neglect this important shift would pay a big price. 


\section{References}

Alavi, M and Leidner, D.E.(2001). Knowledge management and knowledge management systems: conceptual foundations and research issues. Management Information Systems Quarterly.vol.25(1),107-36.

Ancona, D and Caldwell,D.(1992). Bridging the boundary: External activity and performance in organizational teams. Administration Science Quarterly.vol.37(4),634-665

Anumba, C.J, Egbu, C, Carrillo, P.M. (2005) Knowledge Management in Construction. Oxford: Blackwell

Argyris C. (1999) On Organisational learning. Oxford: Blackwell Publishers.

Barber, E and Warn, James. (2005) Leadership in project management: from fire-fighter to firelighter. Management Decision.vol.43(7/8), 1032-1039.

Bass, B (1990) Handbook of Leadership. $3^{\text {rd }}$ ed. New York: Free Press.

Bhatt ,GD (2001) Knowledge management in organizations. Journal of Knowledge Management, 5(1), 68-75.

Blacker, F.(1995). Knowledge, knowledge network and organisations: an overview and interpretations. Organization Studies.vol.15(6),1021-46

Boisot, M. (1987), Information and Organisations: The Manager as Anthropologist, Fontana/Collins, London

Boud, D. (1999) Situating academic development in professional work: using peer learning. International Journal for Academic Development, vol. 4, no. 1, pp. 3-10.

Bourdieu,P (1985)The Forms of Capital. In Handbook of Theory and Research for the Sociology of Education. New York: Greenwood, 241-58.

Bowen HK, Clark KB, Holloway CA and Wheelwright SC. (1994)The perceptual enterprise machine-seven keys to corporate renewal through successful product and process development. New York: Oxford University Press.

Carmichael, D. G. (2006) Project Planning and Control. Abingdon, Oxon: Taylor and Francis. 
Carrillo, Patricia M, Robinson, Herbert S, Anumba, Chimay J, Ahmed AlGhassani.(2003). IMPaKT: A Framework for Linking Knowledge Management to Business Performance. Electronic Journal of Knowledge Management.vol.1(1), 1-12.

Carrillo, P (2005). Lessons learned practices in the engineering, procurement and construction sector. Engineering, Construction and Architectural Management.vol.12(3), 236-250.

Chase, R. (1997), "The knowledge based organisation: an international survey", Journal of Knowledge Management, Vol. 1 No.1.

Chua, A.(2003). Knowledge Sharing: a game people play. Aslib Proceedings.vol.55(3),117-129

Clements, J. P. (2005)Successful Project Management. Mason OH: Thomson/South-Western.

Coleman, R.(1999). What enables self-organising behaviour.Emergence.vol.1, 33-38

Crawford, Lynn, Pollack, J and England, D. (2006). Uncovering the trends in project management: Journal emphases over the last 10 years .International Journal of Project Management.vol.24(2),175-184

Dalgleish, S. .(2003). Are product development projects doomed to fail?.Quality Magazine. < http://www.qualitymag.com/CDA/Archives> [accessed 23.05.2006]

Demerest, M. (1997), "Understanding knowledge management", Journal of Long Range Planning, Vol. 30 No.3, pp.374-84.

Disterer, G.(2002). Management of Project knowledge and experiences. Journal of Knowledge Management.vol.6(5),512-520

Egbu, C.(2006). Knowledge production and capabilities - their importance and challenges for construction organisations in China. Journal of Technology Management in China.vol.1(3), 304-321

Eisenhardt, K and Tabrizi, B.(1995).Accelerating adaptive processes: Product innovation in the global computer industry. Administrative Science Quarterly vol.40(1),84-110. 
Farr-Wharton, R. (2003). Multimedia projects and the optimum choice of individuals and teams. International Journal of Project Management . Vol.21(4),271-280

Galbraith, J. (1973)Designing Complex Organizations. Reading, MA.: Addison Wesley,.

Garrick, J. (1998)Informal Learning in the Workplace: Unmasking Human Resource Development. London: Routledge.

Gladstein, D. L.(1984). Groups in context: a model of task group effectiveness. Administrative Science Quarterly.vol.29 (4),499-517

Ghoshal, S and Bartlett, C.(1988). Creation, adoption, and diffusion of innovations by subsidiaries of multinational corporations. International Business Studies.vol.19(3),365-388.

Gupta, A. K and Govindarajan, V.(2000). Knowledge flows within multinational corporations. Strategic Management Journal .vol.21(4),473-496.

Hackman, J. R. (1987)The design of work teams. Handbook of Organizational Behaviour. Englewood Cliffs, NJ: Prentice Hall.315-42

Hansen, M. T. (1999). The search-transfer problem: The role of weak ties in sharing knowledge across organization subunits. Administrative Science Quarterly.vol.44(1),82-111.

Hansen, M. T.(2002). Knowledge networks: Explaining effective knowledge sharing in multiunit companies. Organization Science.vol.13(3),232-248

Harkema, S.(2003). A complex adaptive perspective on learning within innovation projects. The Learning Organization.vol.10(6),340-346

Hodgson, Damian and Cicmil, Svetlana.(2006)Making projects critical. Basingstoke: Palgrave McMillan.

Hughes, C. (2000) The facilitative role of workplace supervisors, University of Technology, Sydney.

Kakabadse, N.K, Kakabadse, A and Alexander Kouzmin.(2003). Reviewing the Knowledge Management Literature: towards a taxonomy. Journal of Knowledge Management .vol.7(4),75-91 
Kardas, Edward P and Milford, Tommy M. (1996)Using the Internet for social science research and practice. Belmont: Wadsworth Pub.

Kotnour, T. (2000). Organizational learning practices in the project management environment. International Journal of Quality \& Reliability Management.vol.17(4/5),393-406

Kululanga GK and McCaffer R (2001) Measuring knowledge management for construction organizations. Engineering, Construction and Architectural Management, 8(5/6), 346-354.

Lampel, J.(2001). The core competencies of effective project execution: the challenge of diversity. International Journal of Project Management.vol.19(8), 471-483

Lave, J. (1988)Cognition in Practice. Cambridge, MA: Cambridge University Press.

Lee-Kelley, L. .(2002). Situational Leadership: Managing the virtual project team. Journal of Management Development.vol.21(6),461-476

Lester, A.(2006)Project management, planning and control :managing engineering, construction and manufacturing projects to PMI, APM and BSI standards. Oxford: Butterworth-Heinemann.

Leseure, M.J and Brookes, Naomi J.(2004). Knowledge management benchmarks for project management. Journal of Knowledge Management.vol.8.(1),103-116.

Levy, S. M. (2006)Project Management in Construction. New York: McGraw Hill.

Liebowitz, J. (2001) Knowledge Management: learning from knowledge engineering. Boca Raton: CRC Press.

Loosemore, M. e. a. (2006) Risk Management in Projects. Abingdon, Oxon: Taylor and Francis.

Milton, N. (2005)Knowledge management for teams and projects. Oxford: Chandos.

Murdoch, R.(2001). Only brain power can secure the future. The Age.vol.12,15 
Muriithi, $\mathrm{N}$ and Lynn, $\mathrm{N}$ (2003). Approaches to project management in Africa: implications for international development projects. International Journal of Project Management.vol.21,309-319

Nobel, R and Birkinshaw, J. .(1998). Innovation in multinational corporations: Control and communication patterns in international R\&D operations. Strategic Management Journal.vol.19(5),479-496.

Nonaka, I, Takeuchi, K. (1995)The Knowledge Creating Company: How Japanese Companies Create the Dynamics of Innovation. Oxford: Oxford University Press.

Odhiambo, F.O., Harrison, J. and Hepworth, M.(2003). The Use of Sense Making for Understanding the Information Needs of Informal Carers in Leicestershire: An Analysis of the Micro Moment Time Line. Library and Information Research News.vol.27(9),0-1

OECD. (2003)The Learning Government: Introduction and draft results of the survey of Knowledge management practices in ministries/departments/agencies of central Government. Paris: OECD.

Oluikpe, Paul. (2003)Communities of practice in universities. MSc Dissertation, Loughborough University, United Kingdom. Loughborough: Loughborough University.

Project Management Institute.(1996)A guide to the Project Management Body of Knowledge. Upper Darby: PMI.

Robinson HS, Carrillo PM, Anumba CJ and Al-Ghassani AM (2001) Perceptions and barriers in implementing knowledge management strategies in large construction organisations. In Proceedings of RICS Foundation Construction and Building Research Conference - COBRA 2001 (Kelly J and Hunter K, Eds), pp 451-460, Glasgow Caledonian University, Glasgow, U.K.

Robinson, J.P, Sharer, P.R and Wrightsman, L.S. (1991)Criteria for Scale Selection and Evaluation. San Diego, CA: The Academic Press

Rollett, H (2003) Knowledge Management: Processes and Technologies. Kluwer Academic Publishers, Boston

Samid, G. .(2003).The cost of knowledge acquisition. AACE International Transactions.ES261 
Schindler, Martin and Eppler, Martin J.(2003). Harvesting project knowledge: a review of project learning methods and success factors. International Journal of Project Management.vol.21, 219-228

Skyrme, David and Amidon, Debra.(1997). The Knowledge Agenda. Journal of Knowledge Management.vol.1(1),27-37

Szulanski, G.(1996). Exploring internal stickiness: Impediments to the transfer of best practice within the firm. Strategic Management Journal.vol.17,27-43.

Tan, Hai Chen, Carrillo, P, Anumba, C, Kamara, J M, Bouchlaghem, D and Udeaja Chika (2006). Live capture and reuse of project knowledge in construction organisations. Knowledge Management Research \& Practice (2006) 4, 149-161.

Terry, W.(2004). Identifying the hard lessons from projects easily. International Journal of Project Management.vol.22(4),273-279

Trussler, S.(1998). The rules of the game. The Journal of Business Strategy.vol.19(1),16-19

Tushman, M and Scanlan, T. (1977). Boundary spanning individuals: their role in information transfer and their antecedents. Academy of Management Journal.vol.24(3),289-305

Weinkauf, K and Hoegl, M. .(2002). Team leadership activities in different project phases. Team Performance Management: An International Journal.vol.8(7/8),171-182

Wheatley, M.(1992)Leadership and the new science. San Francisco :BerretKoehler.

Wiig, K. (2000). Knowledge management: an emerging discipline rooted in a long history. Knowledge Horizons, Boston, MA: Butterworth-Heinemann

Wiig, K. M.(1997). Knowledge Management: An Introduction and Perspective. Journal of Knowledge Management.vol.1(1),6-14

Wood, J.(2003). Australia: an under-performing knowledge nation ?.Journal of Intellectual Capital.vol.4(2),144-164

von Zedtwitz, M. (2003). Post-project reviews in R\&D. Research-Technology Management.vol.46(5),43-49 


\section{FIGURES}

Figure 1: Nonaka and Takeuchi's model to

\begin{tabular}{|c|c|c|}
\hline & Tacit & Explicit \\
\hline Tacit & Socialisation & Externalisation \\
\hline Explicit & Internalisation & Combination \\
\hline
\end{tabular}


Figure 2: Boisot's model

\begin{tabular}{|c|c|c|}
\cline { 2 - 3 } Codified & $\begin{array}{l}\text { Proprietary } \\
\text { Knowledge }\end{array}$ & $\begin{array}{l}\text { Public } \\
\text { Knowledge }\end{array}$ \\
\cline { 2 - 3 } Uncodified & $\begin{array}{l}\text { Personal } \\
\text { Knowledge }\end{array}$ & Common Sense \\
\cline { 2 - 3 } & Undiffused & Diffused
\end{tabular}


Figure 3: Intellectual Capital model

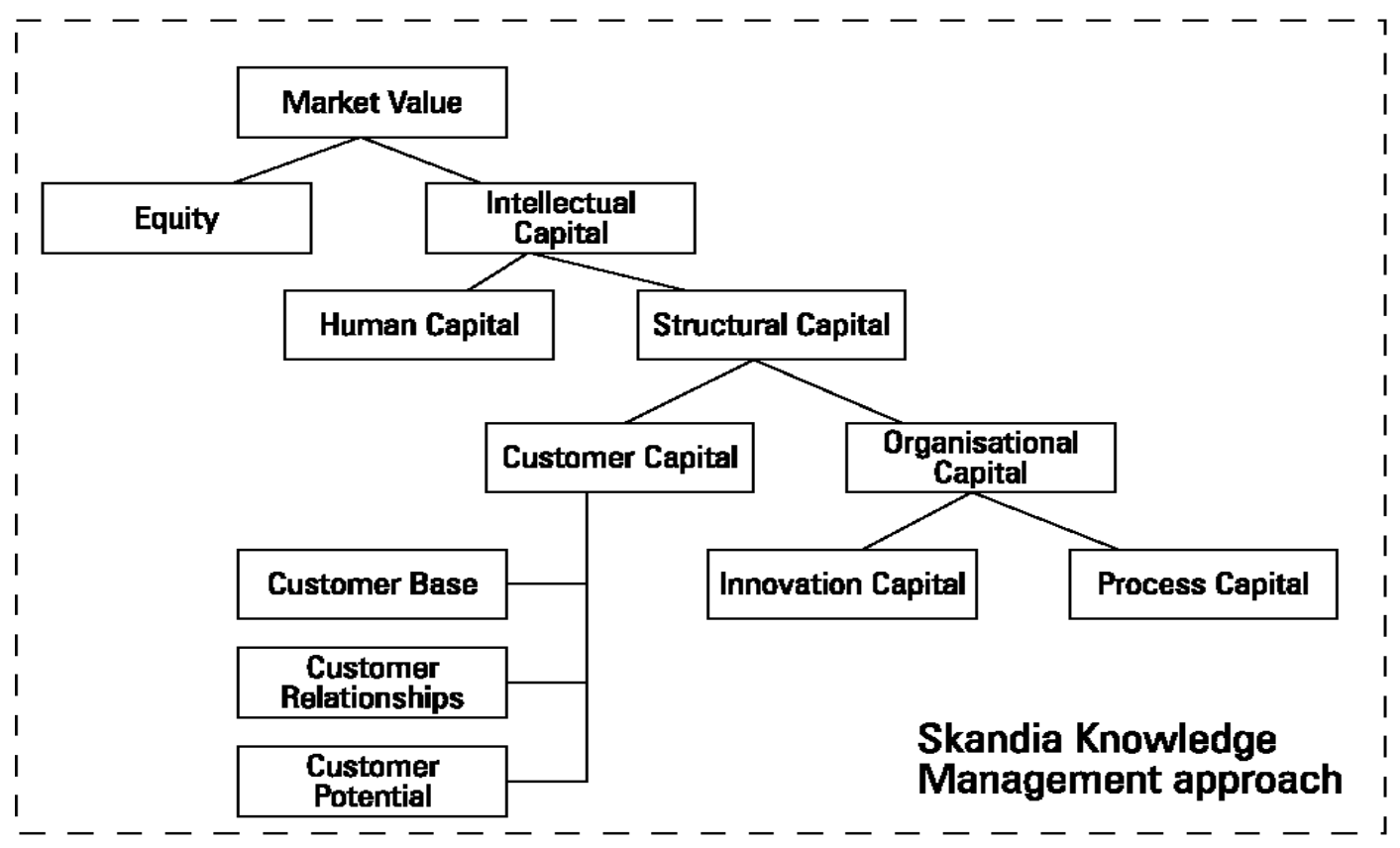

Source: Chase (1997) 
Figure 4: Social Construction model

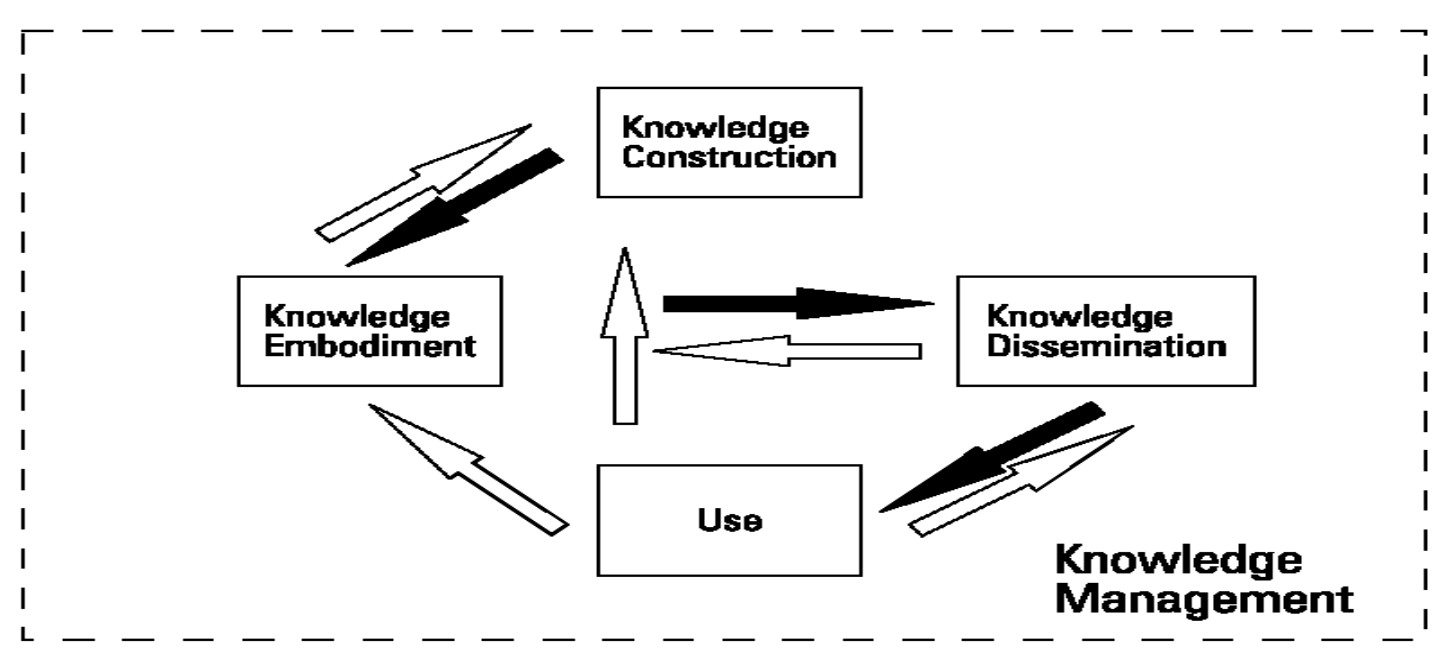

Source: Demerest (1997) 
Figure 5: Analysis of PM as a knowledge generating process

Analysis of PM as a Knowledge generating process

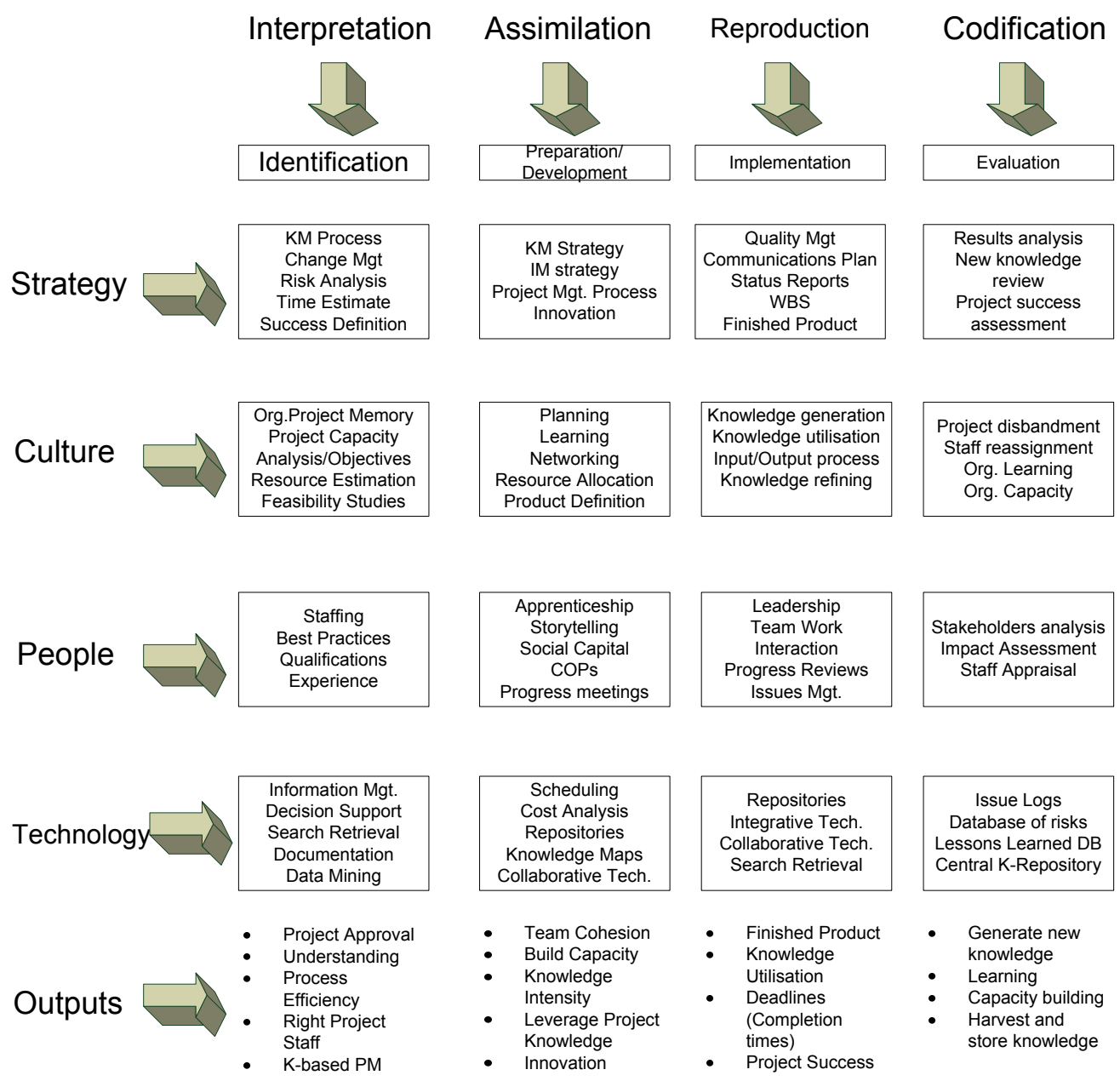


Figure 6: The CRAI model

\section{THE CRAI MODEL}
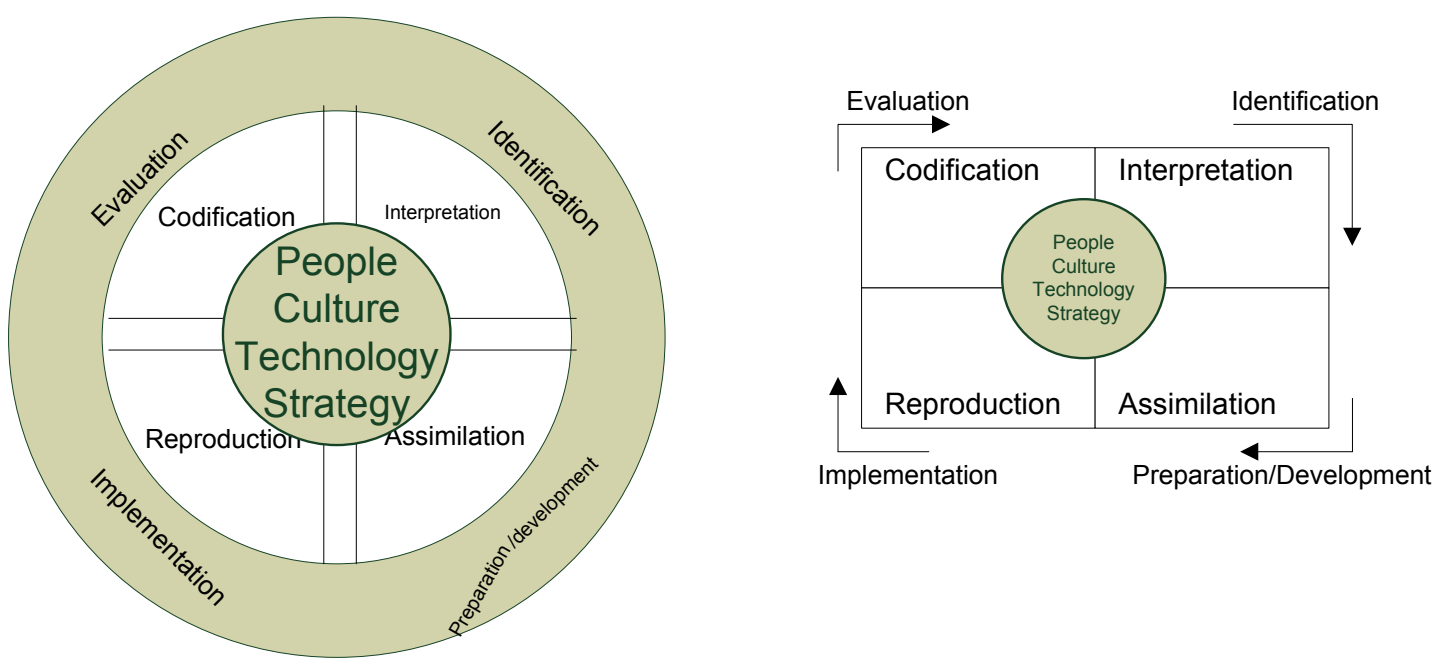
Figure 7: The model constructs

Four Stages of Project Knowledge

Knowledge output of the whole project needing to be captured, codified and stored.

- Evaluation

- Analyse results

- Lessons learnt

- Impact assessment

Reproductive Knowledge

Knowledge assimilated needs to be reproduced on implementation. Project results are direct reproductions of project knowledge assimilated.

- $\quad$ Refine knowledge

- Utilise Knowledge

- Finished product

- Progress review

\section{Interpretative Knowledge}

Immediate and remote knowledge available at the time of project identification needing interpretation to aid project decision

- Experience

- Org. Knowledge

- Documentation

- Decision Support

- Staff

Assimilative Knowledge

Knowledge created during interaction/team formation need to be assimilated for project purposes.

- COPs/Social capital

- Progress meetings

- Networks

- Collaboration

- Process 
Appendix 1: Survey Questionnaire

Knowledge Management in projects

\section{SECTION A: Background Information}

Please indicate which type of project you are currently working on:

- Construction

- Water and Sanitation

- Education

- Technology

- Social services(health,etc)

- Sustainability

- Information

- Women Welfare

- Children and Youth Services

- New Product Development

- Design.

If others not mentioned here please indicate in the text field below.....

What is the number of staff on the project?

- Less than 10

- $10-20$

- 21-30

- $31-40$

- 41-50

- Over 50

What is/was the duration of the project?

- Less than 1 year

- 1 Year

- 2 Years

- 3 Years

- 4 Years

- 5 Years

- More than five years

Please provide your email address if you would like to receive an executive summary of this report 
Please tick the $\mathrm{KM}$ technologies that your project uses to manage knowledge and information.

- Website portal

- Intranet

- Internet

- Groupware

- Agent Technologies

- Content Management System

- Email Group

- Database

Which of these tools do you use to communicate with colleagues during the project ?(Please tick all that apply)

- Email

- Telephone

- Mobile

- Bulletins

- Message Boards

- Chat

- Text Messages

- Newsletters

- Groupware

If others please state.

In which region is your project operating ?

- Europe

- North America

- Latin America

- The Caribbean

- Sub-Saharan Africa

- North Africa

- East Asia

- The Pacific

- Central Asia

- South Asia

- Australia

- Middle East 
What is the status of the project at the moment?

- Completed

- Ongoing

What role do/did you play in the project(Please tick all that apply)

- Manager

- Assistant Manager

- Facilitator

- Director

- Team Member

What is the size of the project?

- Small

- Medium

- Large

\section{SECTION B: KM information}

Please respond to these statements to the degree that they relate to your project at the identification stage. i.e. Strongly disagree, Disagree, No opinion, No response, Agree, Strongly agree

\begin{tabular}{|ll|}
\hline$\bullet$ & We consider a KM process at the initial stage of the project \\
\hline$\bullet$ & Change management is a factor in our project planning \\
\hline$\bullet$ & We conduct a risk analysis of our project at the planning stage \\
\hline$\bullet$ & We estimate the time necessary for completing various aspects of the project \\
\hline$\bullet$ & Our project defines what constitutes success for this particular project \\
\hline$\bullet$ & We reviewed similar project reports/lessons learnt in the past before planning \\
& this project. \\
\hline$\bullet$ & We also conduct feasibility studies at the commencement of the project. \\
\hline & $\begin{array}{l}\text { We consider the experience and qualifications of staff seriously before } \\
\text { - }\end{array}$ Bessigning them to any project \\
\hline & $\begin{array}{l}\text { We had information management plans put into place at the beginning of the } \\
\text { project }\end{array}$ \\
\hline
\end{tabular}

Please respond to these statements to the degree that they relate to your project at the preparation/development stage i.e. Strongly disagree, Disagree, No opinion, No response, Agree, Strongly agree

- $\quad$ There was/is a lot of team work during the project

- Team members helped each other learn on the project and newcomers especially were able to learn from others on the job.

- We held/hold regular progress meetings to review work done, brainstorm and to correct mistakes and also plan ahead for the project.

- There was the presence of informal groups/communities within the project.

- Team members are also allowed and encouraged to communicate with other similar external projects to gain knowledge.

- Project team members are encouraged to share what they know and there are technologies that encourage them to document and share (please also complete the KM technologies section). 
Please respond to these statements to the degree that they relate to your project at the implementation stage i.e. Strongly disagree, Disagree, No opinion, No response, Agree, Strongly agree



Please respond to these statements to the degree that they relate to your project at the evaluation stage i.e. Strongly disagree, Disagree, No opinion, No response, Agree, Strongly agree

\begin{tabular}{|ll|}
\hline - & $\begin{array}{l}\text { The project was analysed at the end against stated objectives and } \\
\text { stakeholders views. }\end{array}$ \\
\hline - & We have a system/process put into place to review our projects \\
\hline - & $\begin{array}{l}\text { We maintain a repository/documentation/reports detailing the activities that } \\
\text { went on from the identification to the evaluation stage of the project. }\end{array}$ \\
\hline - & This report is available for project members and other interested parties. \\
\hline - & $\begin{array}{l}\text { Staff who have been reassigned to other projects could also be reached } \\
\text { when questions regarding the project come up. }\end{array}$ \\
\hline
\end{tabular}

Please respond to the following statements to the degree that they relate to your project outcomes i.e. Strongly disagree, Disagree, No opinion, No response, Agree, Strongly agree

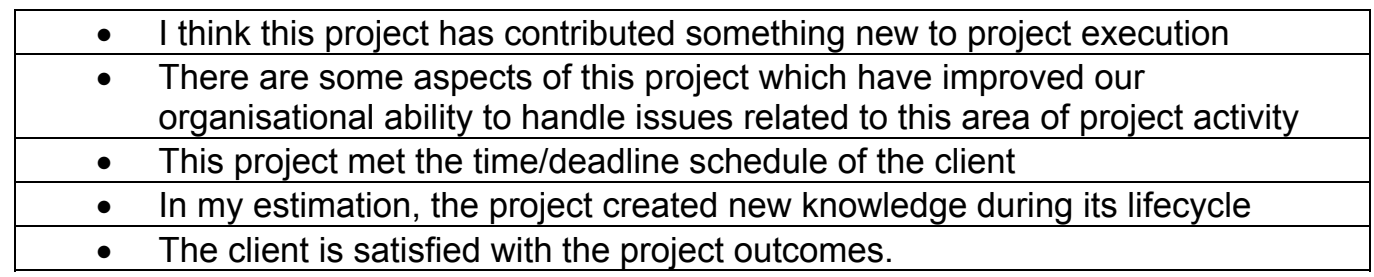

